\title{
Article
}

\section{Bimetallic Cr-In/H-SSZ-13 for selective catalytic reduction of nitric oxide by methane}

\author{
Jun Yang a, Yupeng Chang a, Weili Dai a, Guangjun Wu a, Naijia Guan a,b, Landong Li a,b,* \\ a School of Materials Science and Engineering \& National Institute for Advanced Materials, Nankai University, Tianjin 300071, China \\ ${ }^{\mathrm{b}}$ Key Laboratory of Advanced Energy Materials Chemistry of the Ministry of Education, Collaborative Innovation Center of Chemical Science and \\ Engineering, Nankai University, Tianjin 300071, China
}

\section{A R T I C L E I N F O}

Article history:

Received 7 February 2018

Accepted 7 March 2018

Published 5 May 2018

\section{Keywords:}

Selective catalytic reduction

Nitric oxide

Methane

Cr-In/H-SSZ-13

Bimetallic catalyst

\begin{abstract}
A B S T R A C T
Bimetallic Cr-In/H-SSZ-13 zeolites were prepared by wet impregnation and investigated for selective catalytic reduction of nitric oxide by methane $\left(\mathrm{CH}_{4}\right.$-SCR). Reduction-oxidation treatments led to close contact and interaction between $\mathrm{Cr}$ and In species in these zeolites, as revealed by transmission electron microscopy and X-ray photoelectron spectroscopy. Compared to monometallic $\mathrm{Cr} / \mathrm{H}-\mathrm{SSZ}-13$ and In/H-SSZ-13, the bimetallic catalyst system exhibited dramatically enhanced $\mathrm{CH}_{4}$-SCR performance, i.e., $\mathrm{NO}$ conversion greater than $90 \%$ and $\mathrm{N}_{2}$ selectivity greater than $99 \%$ at $550{ }^{\circ} \mathrm{C}$ in the presence of $6 \% \mathrm{H}_{2} \mathrm{O}$ under a high gas hourly space velocity of $75000 / \mathrm{h}$. The bimetallic $\mathrm{Cr}-\mathrm{In} / \mathrm{H}-\mathrm{SSZ}-13$ showed very good stability in $\mathrm{CH}_{4}$-SCR with no significant activity loss for over 160 h. Catalytic data revealed that $\mathrm{CH}_{4}$ and NO were activated on the In and $\mathrm{Cr}$ sites of Cr-In/H-SSZ-13, respectively, both in the presence of $\mathrm{O}_{2}$ during $\mathrm{CH}_{4}$-SCR.
\end{abstract}

(C) 2018, Dalian Institute of Chemical Physics, Chinese Academy of Sciences. Published by Elsevier B.V. All rights reserved.

\section{Introduction}

Nitrogen oxides derived from boilers, engines, and power plants contribute to the formation of photochemical smog and acid rain and are harmful to human health [1]. The selective catalytic reduction of nitrogen oxides ( $\mathrm{NO}$ and $\mathrm{NO}_{2}$ ) by hydrocarbons (HC-SCR) is a promising strategy for the post-treatment of nitrogen oxides in excess oxygen, and $\mathrm{CH}_{4}$ is an attractive reductant because of its low cost and easy availability in natural gas power plants. In China, $\mathrm{CH}_{4}$-SCR is now attracting particular interest in the move to replace coal with natural gas as a raw material for urban power plants. However, because of its chemical inertness, methane is difficult to activate, which remains a key problem in the $\mathrm{CH}_{4}$-SCR [2-5]. However, NO oxidation, the role of which is still unclear and seems depend- ent on the catalysts employed [6], is an important step in the $\mathrm{CH}_{4}$-SCR.

Zeolites, known as microporous crystalline aluminosilicates, can be directly used as catalysts [7,8] and are more frequently used as catalyst supports [9] in SCR. Transition-metal-modified zeolites have been extensively investigated for $\mathrm{CH}_{4}$-SCR in past decades [10-33]. Among them, In-modified zeolites appear to be most active monometallic catalysts for $\mathrm{CH}_{4}$-SCR because of the effective activation of $\mathrm{CH}_{4}$ by In species [22-29,32]. It was claimed that methane can be activated on $\mathrm{In}_{2} \mathrm{O}_{3}$ sites to generate oxygenates, which then react with nitrate to generate $\mathrm{N}_{2}$ [22]. Alternatively, the $\mathrm{H}_{2} \mathrm{NCO}$ intermediate formed by the reaction between $\mathrm{NO}_{2}$ and partially oxidized methane on intrazeolite $\mathrm{InO}^{+}$sites was proposed to be the actual NO reductant in the $\mathrm{CH}_{4}$-SCR [23]. To improve the $\mathrm{CH}_{4}$-SCR activity, second

\footnotetext{
* Corresponding author. Tel/Fax: +86-22-23500341; E-mail: lild@nankai.edu.cn

This work was supported by the National Natural Science Foundation of China $(21773127,21722303,21421001)$ and the 111 Project (B18030). DOI: 10.1016/S1872-2067(18)63054-2 | http://www.sciencedirect.com/science/journal/18722067| Chin. J. Catal., Vol. 39, No. 5, May 2018
} 
transition metals, e.g., Pd [13,14], Co [3,19], and Ce [20], were introduced to In-zeolites, and the major role of the second transition metals was proposed to promote the oxidative activation of $\mathrm{NO}[3,14,16,20]$. For example, the cobalt oxide clusters in Co-In/HZSM-5 showed a positive effect on the oxidation of $\mathrm{NO}$ to $\mathrm{NO}_{2}$, which promoted the $\mathrm{CH}_{4}$-SCR [3]. Similarly, palladium in Pd-In/H-ZSM-5 promoted the oxidation of NO and increased the formation of the activated nitrate species, while $\mathrm{In}^{+} / \mathrm{InO}^{+}$sites suppressed the formation of less reactive isocyanate and nitrile species [14].

In this work, we aimed to develop an efficient catalyst for the $\mathrm{CH}_{4}$-SCR, i.e., achieving good activity and stability in the presence of excess $\mathrm{H}_{2} \mathrm{O}$ and under high space velocity conditions. H-SSZ-13, a high-silica zeolite with a CHA topology, was first used as a catalytic support for $\mathrm{CH}_{4}$-SCR because of its high stability against framework dealumination. Bimetallic Cr-In/H-SSZ-13 was optimized and its structure-activity relationship in the $\mathrm{CH}_{4}$-SCR was analyzed.

\section{Experimental}

\subsection{Catalyst preparation}

All the chemical reagents employed in this study were of analytical grade from Alfa Aesar and used as received without further purification. Commercial zeolites in their $\mathrm{H}$ form with similar Si/Al ratios of 24, i.e., H-SSZ-13, H-ZSM-5, and H-beta, as well as amorphous $\mathrm{SiO}_{2}$ (surface area of $210 \mathrm{~m}^{2} / \mathrm{g}$ ) were used as supports, and metal modifiers were introduced via wet impregnation. In a typical process, the zeolite support was immersed in a solution containing the desired amount of indium nitrate and chromium nitrate and stirred at room temperature for $24 \mathrm{~h}$. Subsequently, the solvent of the slurry was removed in a rotary evaporator at $80{ }^{\circ} \mathrm{C}$, and the residue was dried in an oven at $80^{\circ} \mathrm{C}$ for $12 \mathrm{~h}$. The obtained solid sample was calcined in $\mathrm{Ar}$ at $550{ }^{\circ} \mathrm{C}$ for $2 \mathrm{~h}$, reduced in $10 \% \mathrm{H}_{2} / \mathrm{Ar}$ at $450{ }^{\circ} \mathrm{C}$ for $1 \mathrm{~h}$, and oxidized in $10 \% \mathrm{O}_{2} / \mathrm{Ar}$ at $450{ }^{\circ} \mathrm{C}$ for $1 \mathrm{~h}$. The final product was denoted as $x \% \mathrm{Cr}-y \% \mathrm{In} / \mathrm{Z}$, where $x \%$ and $y \%$ indicate the weight loadings of $\mathrm{Cr}$ and $\mathrm{In}$, respectively, and $\mathrm{Z}$ indicated the type of zeolite support. Bimetallic In-containing samples, i.e., Me-In/H-SSZ-13 ( $\mathrm{Me}=\mathrm{Ti}, \mathrm{V}, \mathrm{Mn}, \mathrm{Fe}, \mathrm{Co}, \mathrm{Ce}, \mathrm{Zr}$, and Mo), were prepared via similar procedures.

\subsection{Catalyst characterization}

The chemical compositions of samples were analyzed on an IRIS Advantage inductively coupled plasma atomic emission spectrometer.

Transmission electron microscopy (TEM) images of selected samples were acquired on an FEI Tecnai G G $^{2}$ Fo electron microscope. High-angle annular dark-field scanning transmission electron microscopy (HAADF-STEM) images were acquired on an FEI Talos electron microscope. Element mapping analysis was conducted under HAADF-STEM mode using an FEI built-in energy dispersive spectrum.

X-ray photoelectron spectra (XPS) of samples were acquired on a Thermo Scientific ESCALAB 250Xi spectrometer with a monochromatic Al $K_{\alpha}$ X-ray source $(h v=1486.6 \mathrm{eV})$. Accurate binding energies $( \pm 0.1 \mathrm{eV})$ were determined with reference to the $\mathrm{C} 1 \mathrm{~s}$ line of adventitious carbon at $284.8 \mathrm{eV}$.

The temperature-programmed desorption of ammonia ( $\mathrm{NH}_{3}$-TPD) was performed on a Quantachrome ChemBET 3000 chemisorption analyzer. In a typical experiment, the sample was saturated with $5 \% \mathrm{NH}_{3} / \mathrm{He}$ at $50{ }^{\circ} \mathrm{C}$ and then purged with $\mathrm{He}$ at the same temperature for $1 \mathrm{~h}$ to eliminate the physical absorbed ammonia. The $\mathrm{NH}_{3}$ - TPD profile was recorded in flowing $\mathrm{He}$ at a heating rate of $10^{\circ} \mathrm{C} / \mathrm{min}$ from 50 to $600^{\circ} \mathrm{C}$.

The experiments of temperature-programmed reduction by hydrogen ( $\mathrm{H}_{2}$-TPR) were also performed on the Quantachrome ChemBET 3000 chemisorption analyzer. In a typical experiment, a sample of $0.1 \mathrm{~g}$ was pretreated in $10 \% \mathrm{O}_{2} / \mathrm{He}$ at $450{ }^{\circ} \mathrm{C}$ for $1 \mathrm{~h}$, cooled to $50{ }^{\circ} \mathrm{C}$, and purged for $1 \mathrm{~h}$ in flowing He. The $\mathrm{H}_{2}$-TPR profile was recorded in $5 \% \mathrm{H}_{2} / \mathrm{Ar}$ (30 mL/min) at a heating rate of $10{ }^{\circ} \mathrm{C} / \mathrm{min}$. The outlet gas was passed through a dry-ice trap, and the hydrogen consumption was calculated using $\mathrm{CuO}$ as a reference.

\subsection{Catalytic study}

The $\mathrm{CH}_{4}$-SCR reaction was performed in a fixed-bed micro-reactor at atmospheric pressure. Typically, a $0.12 \mathrm{~mL}$ catalyst sample (20-40 mesh) was placed in a quartz reactor and pretreated in $10 \% \mathrm{O}_{2} / \mathrm{Ar}$ at $450{ }^{\circ} \mathrm{C}$ for $1 \mathrm{~h}$. After cooling to the designated temperature in $\mathrm{He}$, the reactant gas mixture ( $\mathrm{NO}=$ 2500 ppm; $\mathrm{CH}_{4}=4000$ ppm; $\mathrm{O}_{2}=4 \%, \mathrm{H}_{2} \mathrm{O}=6 \%$, He balance) was fed to the catalyst to start the reaction. The total flow rate was set at $150 \mathrm{~mL} / \mathrm{min}$ resulting in a gas hourly space velocity (GHSV) of $75000 / \mathrm{h}$. The outlet gas $\left(\mathrm{H}_{2} \mathrm{O}\right.$ removed by cold trap) was analyzed on-line by a NOx analyzer (Ecotech EC9841) and a gas chromatograph (Techcomp GC7900, equipped with a Plot TDX-1 packed column and an FID detector for the analysis of $\mathrm{CH}_{4}$ and $\mathrm{CO}_{x}$, as well as Porapak Q packed column and TCD detector for the analysis of $\mathrm{N}_{2} \mathrm{O}$ and $\mathrm{N}_{2}$ ). During the reaction, the outlet gas stream was analyzed by a mass spectrometer (Pfeiffer Omnistar GSD 320), and the following mass fragments sensible to the system perturbation were monitored: $\mathrm{CH}_{4}(\mathrm{~m} / \mathrm{e}$ $=15), \mathrm{NO} / \mathrm{NO}_{2}(m / e=30), \mathrm{NO}_{2}(m / e=46), \mathrm{O}_{2}(m / e=32), \mathrm{N}_{2}$ $(m / e=28), \mathrm{CO}_{2}(m / e=44), \mathrm{NH}_{3}(m / e=17), \mathrm{H}_{2} \mathrm{O}(m / e=18)$, and $\mathrm{HCHO}(m / e=29)$. The $\mathrm{NO}$ and $\mathrm{CH}_{4}$ conversions are defined as follows:

$$
\begin{gathered}
\mathrm{NO} \text { conversion }=\left([\mathrm{NO}]_{\text {inlet }}-[\mathrm{NO}]_{\text {outlet }}\right) /[\mathrm{NO}]_{\text {inlet }} \times 100 \% \\
\mathrm{NO} \text { conversion to } \mathrm{N}_{2}=2\left[\mathrm{~N}_{2}\right]_{\text {outlet }} /[\mathrm{NO}]_{\text {inlet }} \times 100 \% \\
\mathrm{NO} \text { conversion to } \mathrm{NO}_{2}=\left[\mathrm{NO}_{2}\right]_{\text {outlet }} /[\mathrm{NO}]_{\text {inlet }} \times 100 \% \\
\mathrm{CH}_{4} \text { conversion }=\left(\left[\mathrm{CH}_{4}\right]_{\text {inlet }}-\left[\mathrm{CH}_{4}\right]_{\text {outlet }}\right) /\left[\mathrm{CH}_{4}\right]_{\text {inlet }} \times 100 \% \\
\mathrm{CH}_{4} \text { conversion to } \mathrm{CO}_{2}=\left[\mathrm{CO}_{2}\right]_{\text {outlet }} /\left[\mathrm{CH}_{4}\right]_{\text {inlet }} \times 100 \% \\
\mathrm{CH}_{4} \text { conversion to } \mathrm{CO}=[\mathrm{CO}]_{\text {outlet }} /\left[\mathrm{CH}_{4}\right]_{\text {inlet }} \times 100 \%
\end{gathered}
$$

The temperature-programmed surface reaction (TPSR) of $\mathrm{CH}_{4}$-SCR was performed on a quartz tube reactor, and the products were analyzed on-line by a Pfeiffer Omnistar GSD 320 mass spectrometer.

\section{Results and discussion}

\subsection{Catalyst characterization}


In the representative TEM images of $0.5 \% \mathrm{Cr} / \mathrm{H}-\mathrm{SSZ}-13$ (Fig. 1(a)) and 2\%In/H-SSZ-13 (Fig. 1(b)), irregular polygon-like particles with sizes of a dozen nanometers corresponding to the $\mathrm{Cr}$ - and In-containing species on the surface of H-SSZ-13 zeolite support can be observed. In contrast, much smaller uniform nanoparticles were distributed on zeolite in the case of $0.5 \% \mathrm{Cr}-2 \%$ In/H-SSZ-13 (Fig. 1(c)). From the HAADF-STEM element mapping images (Fig. 1(d) and (e)), the nanoscale aggregations of the $\mathrm{Cr}$ and In species can be clearly identified. Meanwhile, the $\mathrm{Cr}$ and In species seem to be located in the same regions (marked with white dotted circles), revealing the intimate contact between the $\mathrm{Cr}$ and In species. This is further confirmed by a line-scan analysis (red line 1 in Fig. 1(d)) where both the $\mathrm{Cr}$ and In species were detected in a single nanoparticle. Since the $0.5 \% \mathrm{Cr}-2 \% \mathrm{In} / \mathrm{H}-\mathrm{SSZ}-13$ sample was submitted to reduction-oxidation treatments at elevated temperatures (see experiment section for details), the $\mathrm{Cr}$ and In species should exist in the thermodynamically stable states on H-SSZ-13 support, and the intimate contact between the $\mathrm{Cr}$ and In species should originate from their intrinsic properties.

The acidic properties of zeolite catalysts were characterized by means of $\mathrm{NH}_{3}-\mathrm{TPD}$, and the results are shown in Fig. S1. For H-SSZ-13 support, two distinct ammonia desorption peaks were observed corresponding to weak acid sites (peak centered at $200{ }^{\circ} \mathrm{C}$ ) and strong acid sites (peak centered at $450{ }^{\circ} \mathrm{C}$ ). The introduction of $\mathrm{Cr}$ and/or In to H-SSZ-13 resulted in noticeable decreases in the intensity of strong acid sites because of the interaction of $\mathrm{Cr}$ and/or In species with the Brønsted acid sites. Nevertheless, the strong acid sites in parent SSZ-13 zeolite were well preserved after $\mathrm{Cr}$ and/or In impregnation and can participate in both methane activation [34] and NO activation $[9,14]$ for $\mathrm{CH}_{4}$-SCR.

The chemical states of $\mathrm{Cr}$ and In species on the zeolite support were investigated by means of XPS. For $0.5 \% \mathrm{Cr} / \mathrm{H}-\mathrm{SSZ}-13$, binding energy peaks at $586.9\left(2 p_{1 / 2}\right)$ and $577.4\left(2 p_{3 / 2}\right) \mathrm{eV}$ were observed (Fig. 2(a)) corresponding to the mixture of $\mathrm{Cr}^{3+} / \mathrm{Cr}^{6+}[35,36]$. The deconvolution of these peaks was difficult because of the poor signals of $\mathrm{Cr}$ with low loading of $0.5 \%$. For $0.5 \% \mathrm{Cr}-2 \% \mathrm{In} / \mathrm{H}-\mathrm{SSZ}-13$, similar binding energy peaks of $\mathrm{Cr}^{3+} / \mathrm{Cr}^{6+}$ were observed. The difference in the chemical states of $\mathrm{Cr}$ in $0.5 \% \mathrm{Cr} / \mathrm{H}-\mathrm{SSZ}-13$ and $0.5 \% \mathrm{Cr}-2 \% \mathrm{In} / \mathrm{H}-\mathrm{SSZ}-13$, even if
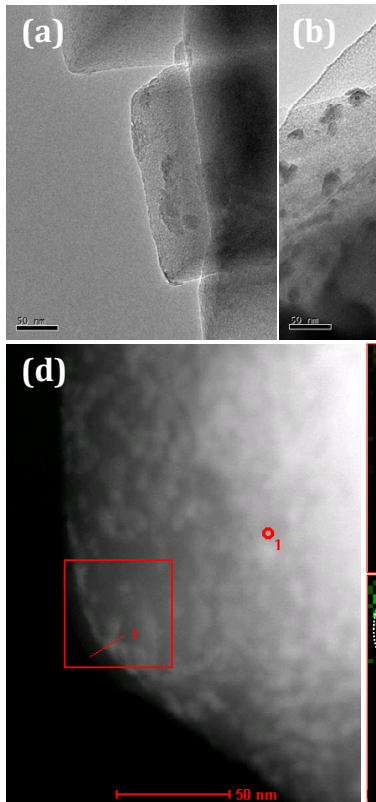

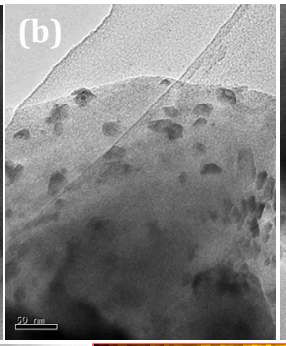

(c)

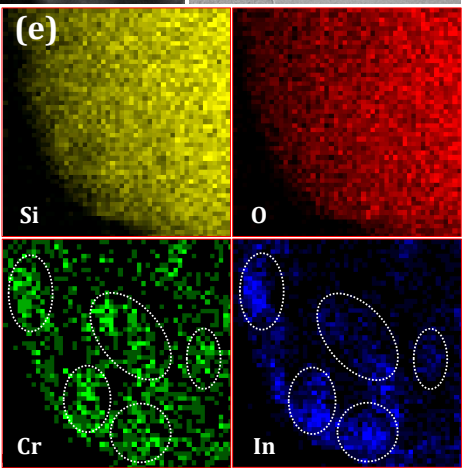

Fig. 1. TEM images of $0.5 \% \mathrm{Cr} / \mathrm{H}-\mathrm{SSZ}-13$ (a), $2 \% \mathrm{In} / \mathrm{H}-\mathrm{SSZ}-13$ (b), $0.5 \% \mathrm{Cr}-2 \% \mathrm{In} / \mathrm{H}-\mathrm{SSZ}-13$ (c); HAADF-STEM image of $0.5 \% \mathrm{Cr}-2 \% \mathrm{In} /$ H-SSZ-13 (d) with corresponding element mapping (e).

existent, could not be distinguished through XPS analysis. In the In $3 d$ XPS, peaks at 453.9 and $446.5 \mathrm{eV}$ were observed for $2 \%$ In/H-SSZ-13 attributed to the $3 d_{3 / 2}$ and $3 d_{5 / 2}$ of $(\operatorname{InO})^{+}$ and/or $\mathrm{In}_{2} \mathrm{O}_{3}$ species interacting with the zeolite support, respectively [18,37]. For $0.5 \% \mathrm{Cr}-2 \% \mathrm{In} / \mathrm{H}-\mathrm{SSZ}-13$, two additional binding energy value signals at 452.5 and $445.0 \mathrm{eV}$ were clearly observed (Fig. 2(b)). Since the sample was finally oxidized in $10 \% \mathrm{O}_{2} / \mathrm{Ar}$ at $450{ }^{\circ} \mathrm{C}$, the presence of low-valence In species can be ruled out. In this context, these binding energies should be related to the oxidized In species interacting with the higher-charge density of $\mathrm{Cr}^{3+} / \mathrm{Cr}^{6+}$. That is, the electron interaction between the $\mathrm{Cr}$ and In species can be revealed by XPS analysis.

The chemical states of the $\mathrm{Cr}$ and In species on the zeolite supports were further examined by TPR, and the $\mathrm{H}_{2}$-TPR profiles are shown in Fig. 3. For 0.5\%Cr/H-SSZ-13 (Fig. 3(b)), a series of reduction peaks in the temperature region $250-550$ ${ }^{\circ} \mathrm{C}$ were observed corresponding to the reduction of $\mathrm{Cr}^{6+}$ to $\mathrm{Cr}^{3+}$
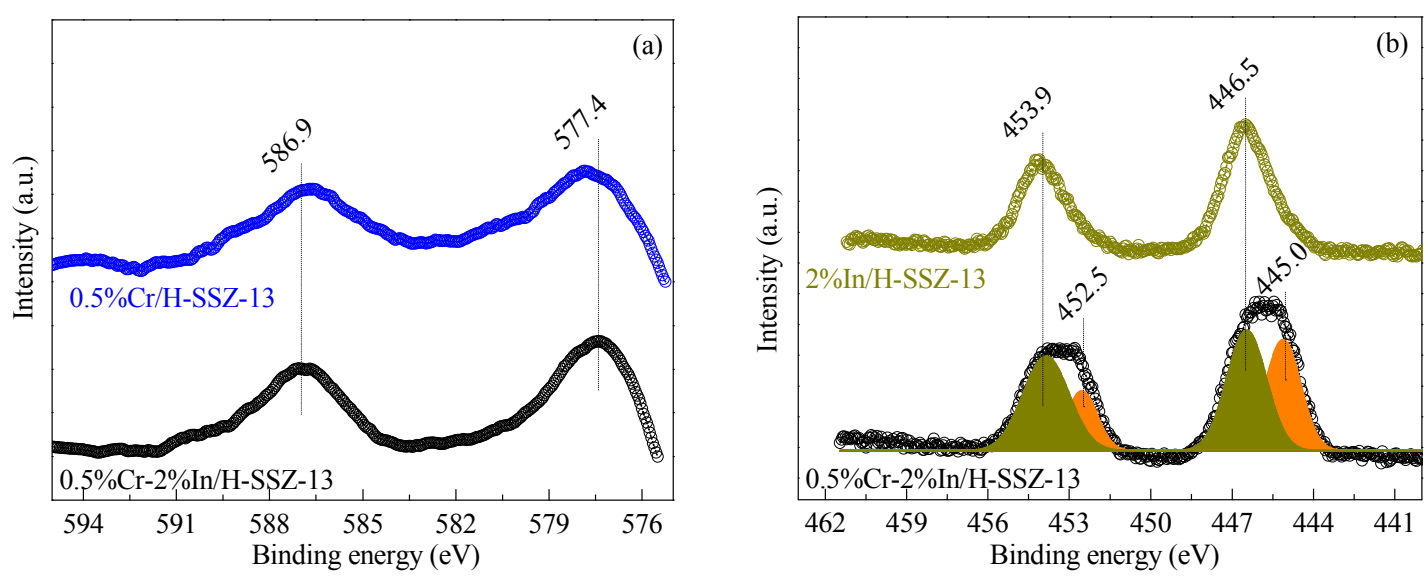

Fig. 2. Cr $2 p$ (a) and In $3 d$ (b) XPS spectra of $0.5 \% \mathrm{Cr} / \mathrm{H}-\mathrm{SSZ}-13$, 2\%In/H-SSZ-13, and 0.5\%Cr-2\%In/H-SSZ-13. 


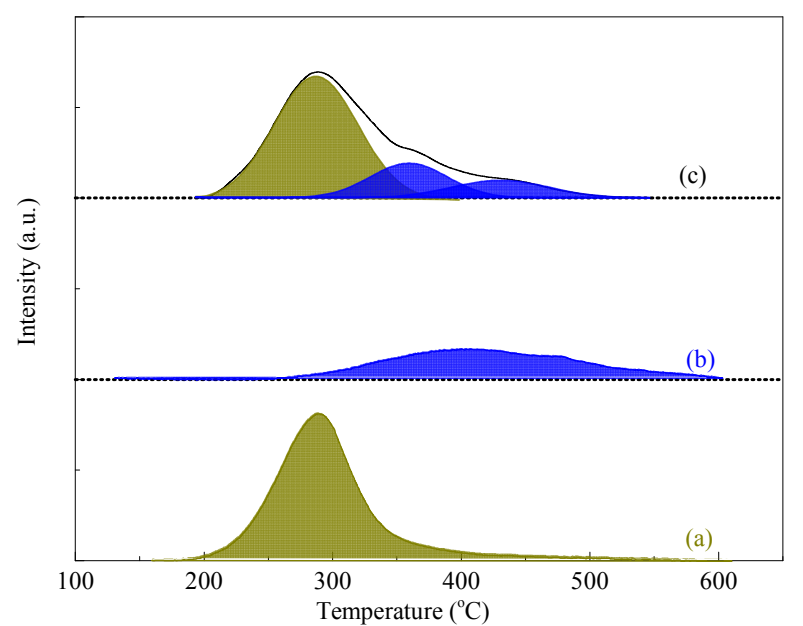

Fig. 3. $\mathrm{H}_{2}$-TPR profiles of $2 \% \mathrm{In} / \mathrm{H}-\mathrm{SSZ}-13$ (a), $0.5 \% \mathrm{Cr} / \mathrm{H}-\mathrm{SSZ}-13$ (b), and $0.5 \% \mathrm{Cr}-2 \% \mathrm{In} / \mathrm{H}-\mathrm{SSZ}-13$ (c).

and/or $\mathrm{Cr}^{3+}$ to $\mathrm{Cr}^{2+}$ in different chemical environments [35,38]. The calculated $\mathrm{H} / \mathrm{Cr}$ ratio was 1.6, confirming the XPS results that a mixture of $\mathrm{Cr}^{3+} / \mathrm{Cr}^{6+}$ species existed in $0.5 \% \mathrm{Cr} / \mathrm{H}-\mathrm{SSZ}-13$ (Fig. 2). For 2\%In/H-SSZ-13 (Fig. 3(a)), a single characteristic reduction peak at $290{ }^{\circ} \mathrm{C}$ with a $\mathrm{H} / \mathrm{In}$ ratio of 1.9 attributed to the reduction of $\mathrm{In}^{3+}$ to $\mathrm{In}^{+}$was observed [26]. In the case of bimetallic $0.5 \% \mathrm{Cr}-2 \%$ In/H-SSZ-13 (Fig. 3(c)), the reduction of the $\mathrm{Cr}$ and In species was well defined: the reduction of the In species was not distinctly affected by the presence of $\mathrm{Cr}(\mathrm{H} / \mathrm{In}=$ 1.8 , reduction peak at $290^{\circ} \mathrm{C}$ ), and the reduction of the $\mathrm{Cr}$ species was affected by the presence of $\mathrm{In}(\mathrm{H} / \mathrm{Cr}=1.6$, two reduction peaks at 360 and $440{ }^{\circ} \mathrm{C}$ ). The similar $\mathrm{H} / \mathrm{In}$ and $\mathrm{H} / \mathrm{Cr}$ ratios observed for bimetallic $0.5 \% \mathrm{Cr}-2 \% \mathrm{In} / \mathrm{H}-\mathrm{SSZ}-13$ reveal the similar overall average oxidation states of the $\mathrm{Cr}$ and In species on the zeolite support with reference to monometallic samples, while the noticeable changes in the reduction peaks corresponding to the $\mathrm{Cr}$ species confirms the electron interaction between $\mathrm{Cr}$ and In as also revealed by XPS (Fig. 2).

\subsection{Catalytic performance of bimetallic $\mathrm{Cr}-\mathrm{In} / \mathrm{H}-\mathrm{SSZ}-13$ in $\mathrm{CH}_{4}-\mathrm{SCR}$}

The catalytic performance of $0.5 \% \mathrm{Cr} / \mathrm{H}-\mathrm{SSZ}-13$, 2\%In/H-SSZ-13 (optimized In loading employed), and $0.5 \% \mathrm{Cr}-2 \% \mathrm{In} / \mathrm{H}-\mathrm{SSZ}-13$ in the $\mathrm{CH}_{4}$-SCR reaction was investigated. As shown in Fig. 4, 0.5\%Cr/H-SSZ-13 (Fig. 4(a)) exhibited very low activity in the $\mathrm{CH}_{4}$-SCR reaction (NO conversion to $\mathrm{N}_{2}<20 \%$ at $550{ }^{\circ} \mathrm{C}$ ), and $2 \% \mathrm{In} / \mathrm{H}-\mathrm{SSZ}-13$ (Fig. 4(b)) exhibited considerable activity (NO conversion to $\mathrm{N}_{2}>40 \%$ at $550{ }^{\circ} \mathrm{C}$ ). The physical mixture of $0.5 \% \mathrm{Cr} / \mathrm{H}-\mathrm{SSZ}-13(0.12 \mathrm{~mL})$ and 2\%In/H-SSZ-13 (0.12 mL) (Fig. 4(c)) appeared to be more ac-
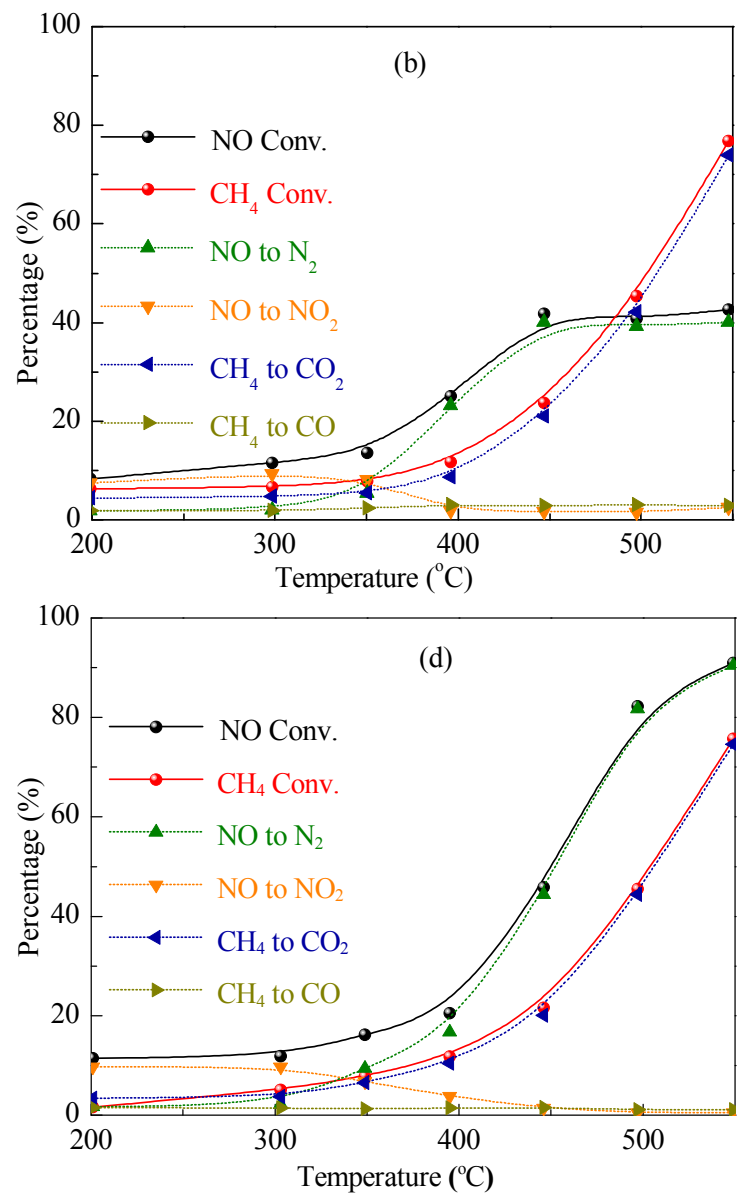

Fig. 4. $\mathrm{CH}_{4}-\mathrm{SCR}$ over $0.5 \% \mathrm{Cr} / \mathrm{H}-\mathrm{SSZ}-13$ (a), $2 \% \mathrm{In} / \mathrm{H}-\mathrm{SSZ}-13$ (b), physical mixture of $0.5 \% \mathrm{Cr} / \mathrm{H}-\mathrm{SSZ}-13$ and $2 \% \mathrm{In} / \mathrm{H}-\mathrm{SSZ}-13$ (c), and $0.5 \% \mathrm{Cr}-2 \% \mathrm{In} / \mathrm{H}-\mathrm{SSZ}-13$ (d). Reaction conditions: $2500 \mathrm{ppm} \mathrm{NO}, 4000 \mathrm{ppm} \mathrm{CH}_{4}, 4 \% \mathrm{O}_{2}, 6 \% \mathrm{H}_{2} \mathrm{O}$, He balance; GHSV = $75000 / \mathrm{h}$. 
tive, but it acted more like a simple accumulation of two individual components. In contrast, bimetallic $0.5 \% \mathrm{Cr}-2 \% \mathrm{In} /$ H-SSZ-13 (Fig. 4(d)) was very active in the $\mathrm{CH}_{4}$-SCR reaction. Typically, NO conversion increased from $10 \%$ to more than $90 \%$ with an increasing reaction temperature from 300 to 550 ${ }^{\circ} \mathrm{C}$, and $\mathrm{N}_{2}$ selectivity greater than $99 \%$ was obtained at temperatures greater than $450{ }^{\circ} \mathrm{C}$. Obviously, a cooperative effect between the $\mathrm{Cr}$ and In species did exist and played a key role in the $\mathrm{CH}_{4}$-SCR reaction catalyzed by bimetallic $0.5 \% \mathrm{Cr}-2 \% \mathrm{In} /$ $\mathrm{H}$-SSZ-13. In other words, the presence of $\mathrm{Cr}$ dramatically promoted the $\mathrm{CH}_{4}-\mathrm{SCR}$ reaction over In/H-SSZ-13.

The catalytic performance of bimetallic Cr-In on different supports was investigated. As shown in Fig. 5, the support materials played a decisive role in the $\mathrm{CH}_{4}$-SCR activity of the $\mathrm{Cr}$-In catalysts. H-SSZ-13 appears to be the best support for the $\mathrm{Cr}$-In active species, followed by H-ZSM-5. H-beta and $\mathrm{SiO}_{2}$ are not suitable support materials, and very low $\mathrm{CH}_{4}$-SCR activity was observed for $\mathrm{Cr}-\mathrm{In} / \mathrm{H}$-beta and $\mathrm{Cr}-\mathrm{In} / \mathrm{SiO}_{2}$. H-SSZ-13 can be clearly optimized from all the support materials investigated. An extra advantage of using H-SSZ-13 as support is its remarkable thermal and hydrothermal stability, which should be good for the catalytic stability of $0.5 \% \mathrm{Cr}-2 \% \mathrm{In} / \mathrm{H}-\mathrm{SSZ}-13$ at elevated temperatures and in the presence of excess $\mathrm{H}_{2} \mathrm{O}$ (vide infra).

A series of bimetallic In-containing zeolite catalysts were further applied in the $\mathrm{CH}_{4}$-SCR reaction to elaborate the unique promotion effect of the $\mathrm{Cr}$ species. As shown in Fig. 6, some elements, i.e., $\mathrm{Fe}, \mathrm{V}, \mathrm{Mo}, \mathrm{Cr}, \mathrm{Ce}$, and Co show promotion effects on In/H-SSZ-13 for the $\mathrm{CH}_{4}$-SCR reaction, while others (Ti, Mn, and $\mathrm{Zr}$ ) do not. It has been reported that $\mathrm{Ce}[20]$ and $\mathrm{Co}[3,19]$ can significantly promote the $\mathrm{CH}_{4}-\mathrm{SCR}$ reaction over In/zeolites, and similar promotion effects were observed here. Fortunately, the best promotion effect of $\mathrm{Cr}$ on In/H-SSZ-13 for $\mathrm{CH}_{4}$-SCR was disclosed for the first time in this study. To our knowledge, bimetallic $0.5 \% \mathrm{Cr}-2 \% \mathrm{In} / \mathrm{H}-\mathrm{SSZ}-13$ appears to be the most active $\mathrm{CH}_{4}$-SCR catalysts under comparable reaction conditions, i.e., high NO inlet concentration, high GHSV, and excessive $\mathrm{H}_{2} \mathrm{O} \quad[3,10,14,30,39]$. For bimetallic $x \% \mathrm{Cr}-2 \% \mathrm{In} /$ $\mathrm{H}-\mathrm{SSZ}-13$ catalysts, increasing the $\mathrm{Cr}$ loading from $0.2 \%$ to $0.5 \%$ showed noticeable positive impacts on the $\mathrm{CH}_{4}$-SCR activ-

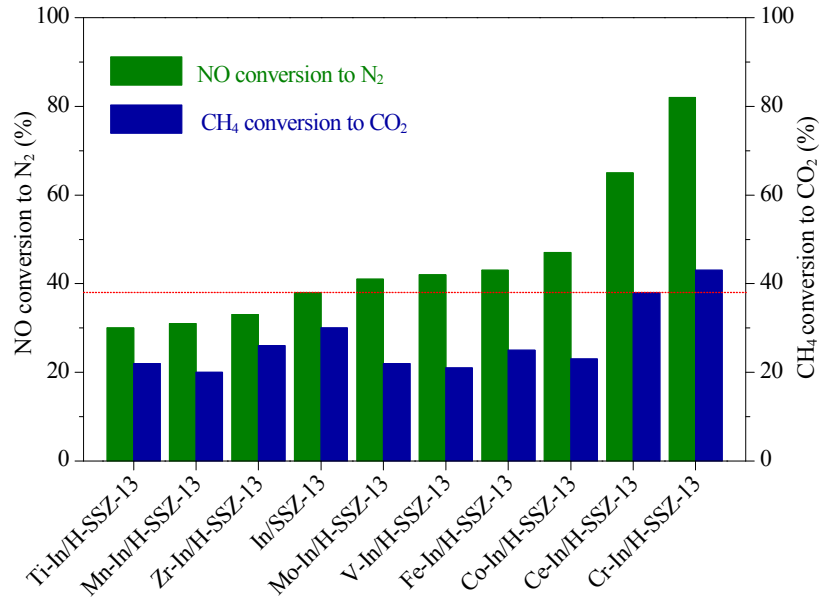

Fig. 6. Comparison of In-based bimetallic catalysts supported on H-SSZ-13 for $\mathrm{CH}_{4}$-SCR. Reaction conditions: 2500 ppm NO, 4000 ppm $\mathrm{CH}_{4}, 4 \% \mathrm{O}_{2}, 6 \% \mathrm{H}_{2} \mathrm{O}$, He balance; $T=500{ }^{\circ} \mathrm{C} ; \mathrm{GHSV}=75000 / \mathrm{h}$.

ity, while further increases of $\mathrm{Cr}$ loading to $1 \%$ had no significant effect (Fig. S2).

Some reaction parameters, e.g., space velocity (Fig. S3) and $\mathrm{O}_{2}$ and $\mathrm{CH}_{4}$ concentration in feeding gas (Fig. S4), were also investigated. In the absence of $\mathrm{O}_{2}$, relatively low $\mathrm{NO}$ conversion to $\mathrm{N}_{2}$ was observed above $300^{\circ} \mathrm{C}$, which should come from the direct decomposition of NO (Eq. (4)). The introduction of $\mathrm{O}_{2}$ to the reaction system can help to activate $\mathrm{NO}$ and/or $\mathrm{CH}_{4}$, and, therefore, trigger the $\mathrm{CH}_{4}-\mathrm{SCR}$ reaction $[39,40]$. More $\mathrm{O}_{2}$ can slightly promote $\mathrm{NO}$ oxidation below $300{ }^{\circ} \mathrm{C}$ and $\mathrm{CH}_{4}$ oxidation at temperatures greater than $400{ }^{\circ} \mathrm{C}$. In this study, excess $\mathrm{CH}_{4}$ was employed for NO (Eq. (1)) since $\mathrm{CH}_{4}$ is cheap and easily available in natural gas power plants and the unreacted $\mathrm{CH}_{4}$ can be removed by catalytic combustion (Eqs. (2) and (3)). As expected, changing the $\mathrm{CH}_{4}$ concentration within the range 3000-5000 ppm did not significantly influence the $\mathrm{CH}_{4}$-SCR activity, while the efficiency of the $\mathrm{CH}_{4}$ reducing agent differed slightly (Fig. S4).

According to our experimental observations and literature reports $[4,23]$, the possible reactions during $\mathrm{CH}_{4}$-SCR are iden-
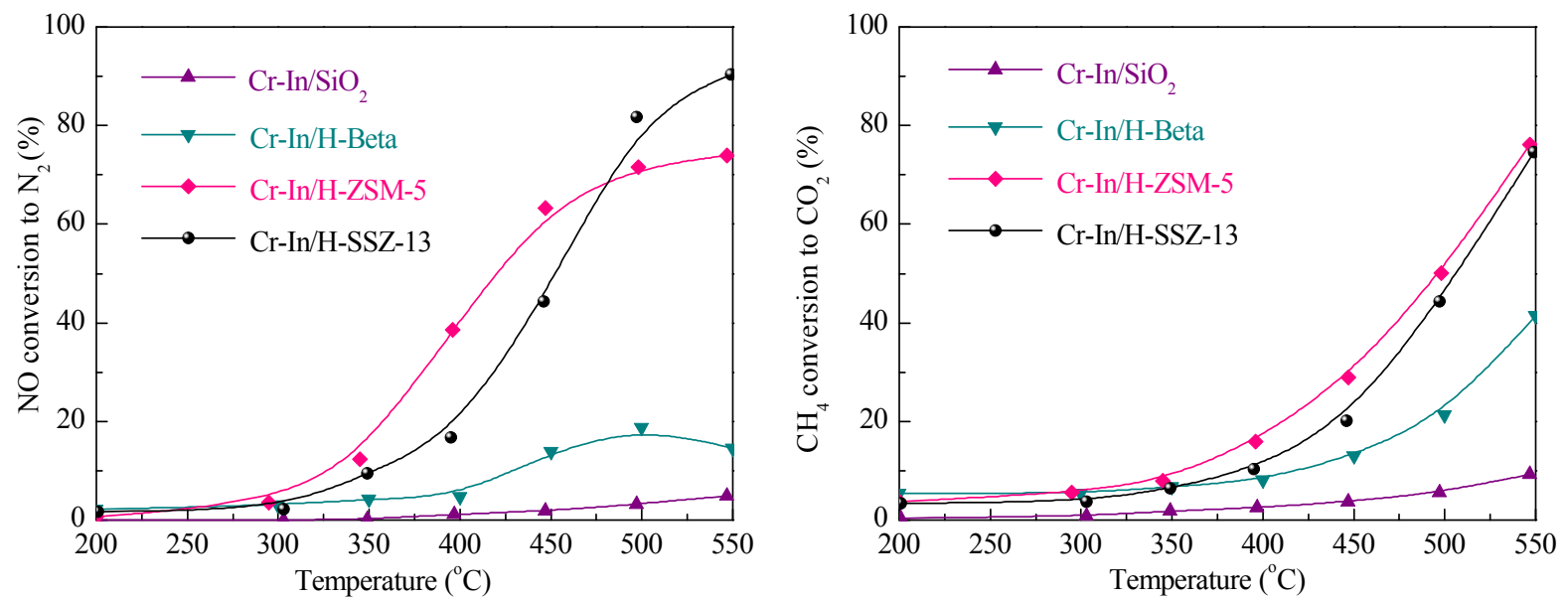

Fig. 5. $\mathrm{CH}_{4}$-SCR over $0.5 \% \mathrm{Cr}-2 \% \mathrm{In} / \mathrm{SiO}_{2}, 0.5 \% \mathrm{Cr}-2 \% \mathrm{In} / \mathrm{H}-\mathrm{ZSM}-5,0.5 \% \mathrm{Cr}-2 \% \mathrm{In} / \mathrm{H}-$ beta, and $0.5 \% \mathrm{Cr}-2 \% \mathrm{In} / \mathrm{H}-\mathrm{SSZ}-13$ (Si/Al = 25). Reaction conditions: 2500 ppm NO, $4000 \mathrm{ppm} \mathrm{CH}_{4}, 4 \% \mathrm{O}_{2}, 6 \% \mathrm{H}_{2} \mathrm{O}$, He balance; GHSV = $75000 / \mathrm{h}$. 
tified below:

$$
\begin{aligned}
2 \mathrm{NO}+\mathrm{CH}_{4}+\mathrm{O}_{2} & \rightarrow \mathrm{N}_{2}+2 \mathrm{H}_{2} \mathrm{O}+\mathrm{CO}_{2} \\
\mathrm{CH}_{4}+2 \mathrm{O}_{2} & \rightarrow 2 \mathrm{H}_{2} \mathrm{O}+\mathrm{CO}_{2} \\
2 \mathrm{CH}_{4}+3 \mathrm{O}_{2} & \rightarrow 4 \mathrm{H}_{2} \mathrm{O}+2 \mathrm{CO} \\
2 \mathrm{NO} & \rightarrow \mathrm{N}_{2}+\mathrm{O}_{2} \\
2 \mathrm{NO}+\mathrm{O}_{2} & \rightarrow 2 \mathrm{NO}_{2} \\
2 \mathrm{CO}+2 \mathrm{NO} & \rightarrow \mathrm{N}_{2}+2 \mathrm{CO}_{2}
\end{aligned}
$$

Among these reactions, $\mathrm{CH}_{4}$ oxidation to $\mathrm{CO}_{2}$ or $\mathrm{CO}$ by $\mathrm{O}_{2}$ (Eqs. (2) and (3)) and $\mathrm{NO}$ oxidation to $\mathrm{NO}_{2}$ by $\mathrm{O}_{2}$ (Eq. (5)) are known as major side reactions. However, they are related to the activation of $\mathrm{CH}_{4}$ and NO, respectively, and show significant impacts on $\mathrm{CH}_{4}$-SCR. Therefore, the reactions catalyzed by $0.5 \% \mathrm{Cr} / \mathrm{H}-\mathrm{SSZ}-13, \quad 2 \% \mathrm{In} / \mathrm{H}-\mathrm{SSZ}-13$, and $0.5 \% \mathrm{Cr}-2 \% \mathrm{In} /$ H-SSZ-13 were investigated. As shown in Fig. S5, noticeable NO oxidation to $\mathrm{NO}_{2}$ with maximal NO conversion of $25 \%$ was achieved in the temperature range $200-450{ }^{\circ} \mathrm{C}$ over all three catalysts. Obviously, $\mathrm{Cr}$ does not significantly promote the oxidation of $\mathrm{NO}$ to gaseous $\mathrm{NO}_{2}$. Moreover, the gas-phase $\mathrm{NO}_{2}$ formation is not the rate-determining step in $\mathrm{CH}_{4}$-SCR since the $\mathrm{CH}_{4}$-SCR rate is apparently higher than that of $\mathrm{NO}$ oxidation (Figs. 4 and S5).

For $\mathrm{CH}_{4}$ oxidation, $0.5 \% \mathrm{Cr} / \mathrm{H}-\mathrm{SSZ}-13$ exhibited relatively low activity and a considerable amount of $\mathrm{CO}$ was produced from incomplete oxidation (Fig. S6). 2\%In/H-SSZ-13 exhibited moderate activity in $\mathrm{CH}_{4}$ oxidation, with $\mathrm{CO}_{2}$ as the dominating product. $0.5 \% \mathrm{Cr}-2 \% \mathrm{In} / \mathrm{H}-\mathrm{SSZ}-13$ appeared to be more active than $0.5 \% \mathrm{Cr} / \mathrm{H}-\mathrm{SSZ}-13$ and $2 \% \mathrm{In} / \mathrm{H}-\mathrm{SSZ}-13$, and the formation of $\mathrm{CO}$ as observed in the case of $0.5 \% \mathrm{Cr} / \mathrm{H}-\mathrm{SSZ}-13$ was significantly suppressed. These observations indicate the cooperation between $\mathrm{Cr}$ and In during $\mathrm{CH}_{4}$ oxidation. It has been claimed that $\mathrm{CH}_{4}$ oxidation competes with $\mathrm{CH}_{4}$-SCR, especially at high temperatures, and higher $\mathrm{CH}_{4}$ oxidation activity may lead to lower $\mathrm{CH}_{4}$-SCR activity [41]. However, $\mathrm{CH}_{4}$ oxidation activity may indicate the capability of $\mathrm{CH}_{4}$ activation, which is also very important for $\mathrm{CH}_{4}$-SCR. Since excess $\mathrm{CH}_{4}$ was employed in the $\mathrm{CH}_{4}$-SCR in this study, higher $\mathrm{CH}_{4}$ oxidation activity correlates with higher $\mathrm{CH}_{4}$-SCR activity (Figs. 4 and $\mathrm{S6}$ ).

The stability of $0.5 \% \mathrm{Cr}-2 \% \mathrm{In} / \mathrm{H}-\mathrm{SSZ}-13$ during $\mathrm{CH}_{4}-\mathrm{SCR}$ at $500{ }^{\circ} \mathrm{C}$ was investigated. As shown in Fig. 7, NO conversion to $\mathrm{N}_{2}$ over $0.5 \% \mathrm{Cr}-2 \% \mathrm{In} / \mathrm{H}-\mathrm{SSZ}-13$ was very stable for the first 30 $\mathrm{h}$ of the $\mathrm{CH}_{4}$-SCR reaction in the absence of $\mathrm{H}_{2} \mathrm{O}$ (NO conversion

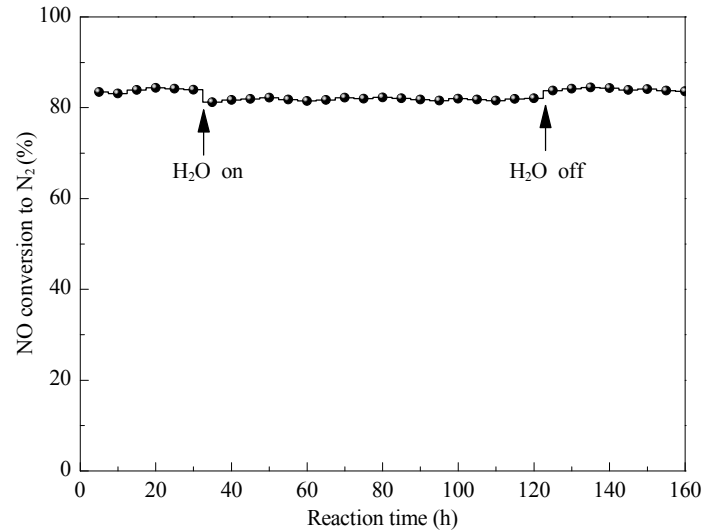

Fig. 7. Stability test of $0.5 \% \mathrm{Cr}-2 \% \mathrm{In} / \mathrm{H}-\mathrm{SSZ}-13$ in $\mathrm{CH}_{4}-\mathrm{SCR}$. Reaction conditions: 2500 ppm NO, $4000 \mathrm{ppm} \mathrm{CH}_{4}, 4 \% \mathrm{O}_{2}, 0$ or $6 \% \mathrm{H}_{2} \mathrm{O}$, He balance; $T=500{ }^{\circ} \mathrm{C} ; \mathrm{GHSV}=75000 / \mathrm{h}$.

of $84 \%$ ). The introduction of $6 \% \mathrm{H}_{2} \mathrm{O}$ to the reaction system caused a slight decrease in NO conversion to $82 \%$, which was stable for the next $90 \mathrm{~h}$. After the feeding of $\mathrm{H}_{2} \mathrm{O}$ was stopped, the NO conversion gradually recovered to the initial value and remained at this level for a further $30 \mathrm{~h}$. These observations indicate that the presence of excess $\mathrm{H}_{2} \mathrm{O}$ shows reversible negative impacts on $\mathrm{CH}_{4}$-SCR, probably by competing adsorption on the active sites. The remarkable catalytic stability of $0.5 \% \mathrm{Cr}-2 \% \mathrm{In} / \mathrm{H}-\mathrm{SSZ}-13$ can be explained from the stability of both the bimetallic active centers and the zeolite support. Through reduction-oxidation treatment, bimetallic Cr-In species exist in the thermodynamically stable states and their structures during reaction will not change. Meanwhile, H-SSZ-13 zeolite was very stable upon thermal and hydrothermal treatments, and the structure destruction because of the framework dealumination was completely suppressed. On the whole, $0.5 \% \mathrm{Cr}-2 \% \mathrm{In} / \mathrm{H}-\mathrm{SSZ}-13$ appears to be an eligible $\mathrm{CH}_{4}$-SCR catalyst for potential applications.

\subsection{Reaction intermediate}

The reaction intermediates in $\mathrm{CH}_{4}$-SCR were investigated by means of TPSR, and the results are shown in Fig. 8. The activity difference in $\mathrm{CH}_{4}$-SCR was well identified and in good agree-
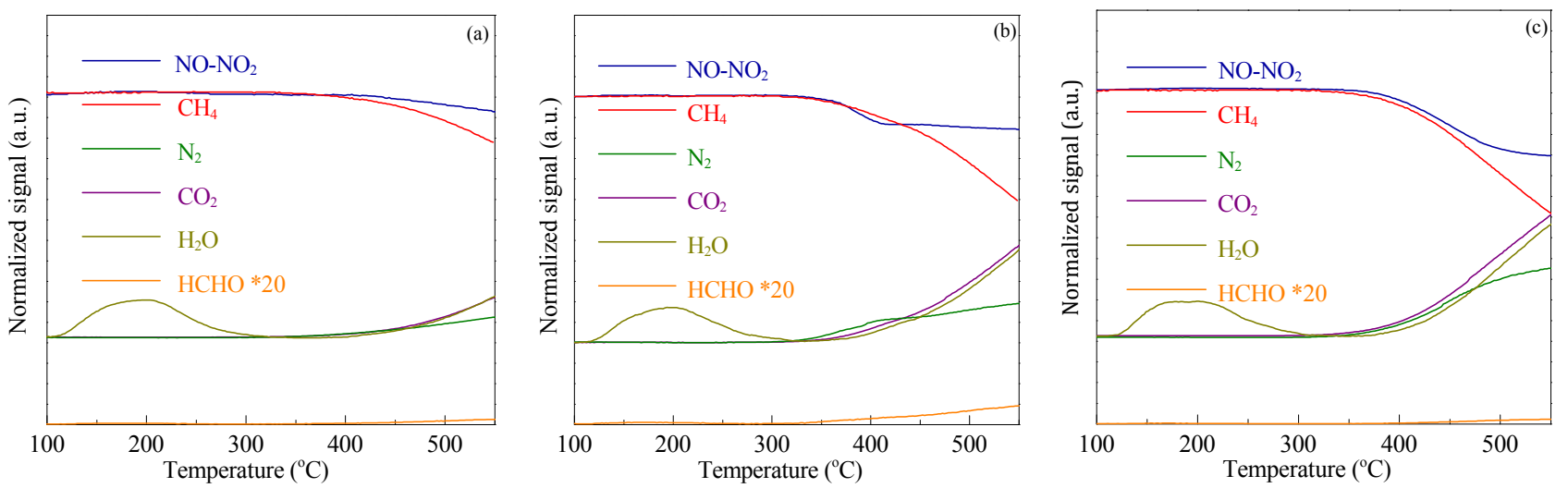

Fig. 8. TPSR of $\mathrm{CH}_{4}$-SCR over $0.5 \% \mathrm{Cr} / \mathrm{H}-\mathrm{SSZ}-13$ (a), 2\%In/H-SSZ-13 (b), and $0.5 \% \mathrm{Cr}-2 \%$ In/H-SSZ-13 (c). Reaction conditions: 0.1 g catalyst, 2500 ppm NO, $4000 \mathrm{ppm} \mathrm{CH}_{4}, 4 \% \mathrm{O}_{2}$, He balance; total flow rate $=100 \mathrm{~mL} / \mathrm{min}$. 
ment with the steady-state reaction results (Fig. 4). Formaldehyde (HCHO) from the incomplete oxidation of methane was detected as the exclusive carbon-containing intermediate gaseous product during $\mathrm{CH}_{4}$-SCR over $2 \% \mathrm{In} / \mathrm{H}-\mathrm{SSZ}-13$, indicating the oxidative activation of $\mathrm{CH}_{4}$ to $\mathrm{HCHO}$ over the In species. The further oxidation of $\mathrm{HCHO}$ (by $\mathrm{O}_{2}, \mathrm{NO}, \mathrm{NO}_{2}$, or other oxidants) to $\mathrm{H}_{2} \mathrm{O}$ and $\mathrm{CO}_{2}$ was apparently a slow step over $2 \%$ In/H-SSZ-13. While in the case of $0.5 \% \mathrm{Cr}-2 \% \mathrm{In} / \mathrm{H}-\mathrm{SSZ}-13$, the formation of HCHO was greatly suppressed and a rational explanation is that the further oxidation of $\mathrm{HCHO}$ was promoted by the presence of the $\mathrm{Cr}$ species. Another interesting phenomenon is that the conversion of $\mathrm{NO} / \mathrm{NO}_{2}$ to $\mathrm{N}_{2}$ was faster than the $\mathrm{CH}_{4}$ conversion to $\mathrm{CO}_{2}$ over $2 \% \mathrm{In} / \mathrm{H}-\mathrm{SSZ}-13$ (Fig. 8(b)), hinting to a mechanism of NO decomposition followed by oxygen removal. In contrast, a synchronous conversion of $\mathrm{NO} / \mathrm{NO}_{2}$ and $\mathrm{CH}_{4}$ was observed over bimetallic $0.5 \% \mathrm{Cr}-2 \%$ In/H-SSZ-13 (Fig. 8(c)). According to the TPSR results, we propose that the activation of NO occurs on $\mathrm{Cr}$ species, while the activation of $\mathrm{CH}_{4}$ occurs on In species. The cooperation between $\mathrm{Cr}$ and In species is responsible for the remarkable $\mathrm{CH}_{4}-\mathrm{SCR}$ activity of $0.5 \% \mathrm{Cr}-2 \% \mathrm{In} / \mathrm{H}-\mathrm{SSZ}-13$ in accordance with the steady-state reaction results.

\section{Conclusions}

Bimetallic $0.5 \% \mathrm{Cr}-2 \% \mathrm{In} / \mathrm{H}-\mathrm{SSZ}-13$ was successfully developed as a robust catalyst for $\mathrm{CH}_{4}$-SCR, outperforming monometallic Cr/H-SSZ-13, In/H-SSZ-13, and their mixture. Typically, NO conversion greater than $90 \%$ with $\mathrm{N}_{2}$ selectivity greater than $99 \%$ was achieved at $550{ }^{\circ} \mathrm{C}$ and high GHSV of $75000 / \mathrm{h}$ in the presence of $6 \% \mathrm{H}_{2} \mathrm{O}$. Through reduction-oxidation treatments, $\mathrm{Cr}$ and In species existed in the thermodynamically stable states on H-SSZ-13. TEM images and XPS results revealed a close contact between $\mathrm{Cr}$ and In species as well as their interaction, which is helpful for constructing an efficient cooperative catalysis system. According to the catalytic data, the activation of $\mathrm{CH}_{4}$ and $\mathrm{NO}$ occurred on the In and $\mathrm{Cr}$ sites of bimetallic Cr-In/H-SSZ-13, respectively, both with the participation of $\mathrm{O}_{2}$.

\section{Supporting Information}

More characterization results and catalytic results in $\mathrm{CH}_{4}-\mathrm{SCR}$

\section{References}

[1] European Environment Agency, Nitrogen Oxides $\left(\mathrm{NO}_{x}\right)$ Emissions. 2010, 1-20.

[2] F. Lónyi, H. E. Solt, Z. Pászti, J. Valyon, Appl. Catal. B, 2014, 150-151, 218-229.

[3] F. Lónyi, H. E. Solt, J. Valyon, A. Boix, L. B. Gutierrez, Appl. Catal. B, 2012, 117-118, 212-223.

[4] J. N. Armor, Catal. Today, 1995, 26, 147-158.

[5] N. W. Cant, I. O. Y. Liu, Catal. Today, 2000, 63, 133-146.

[6] J. A Loiland, R. F. Lobo, J. Catal., 2015, 325, 68-78.

[7] M. Wallin, C. J. Karlsson, M. Skoglundh, A. Palmqvist, J. Catal., 2003, $218,354-364$.

[8] S. A. Stevenson, J. C. Vartuli, C. F. Brooks, J. Catal., 2000, 190, 228-239.

[9] R. D. Zhang, N. Liu, Z. G. Lei, B. H. Chen, Chem. Rev., 2016, 116, 3658-3721.

[10] A. N. Mendes, V. L. Zholobenko, F. Thibault-Starzykc, P. Da Costa, C. Henriques, Appl. Catal. B, 2016, 195, 121-131.

[11] I. O. Costilla, M. D. Sanchez, M. A. Volpe, C. E. Gigola, Catal. Today, 2011, 172, 84-89.

[12] J. A. Z. Pieterse, S. Booneveld, Appl. Catal. B, 2007, 73, 327-335.

[13] H. Decolatti, H. Solt, F. Lónyi, J. Valyon, E. Miró, L. Gutierrez, Catal. Today, 2011, 172, 124-131.

[14] F. Lónyi, H. E. Solt, J. Valyon, H. Decolatti, L. B. Gutierrez, E. Miró, Appl. Catal. B, 2010, 100, 133-142.

[15] L. Gutierrez, A. Boix, J. O. Petunchi, J. Catal., 1998, 179, 179-191.

[16] F. Lonyi, J. Valyon, L. Gutierrez, M. A. Ulla, E. A. Lombardo, Appl. Catal. B, 2007, 73, 1-10.

[17] L. Gutierrez, E. A. Lombardo, Appl. Catal. A, 2009, 360, 107-119.

[18] H. P. Decolatti, E. G. Gioria, S. N. Ibarlín, N. Navascues, S. Irusta, E. E. Miro, L. B. Gutierrez, Microporous Mesoporous Mater., 2016, 222, 9-22.

[19] F. Lónyi, H. E. Solt, J. Valyon, A. Boix, L. B. Gutierrez, J. Mol. Catal. A, 2011, 345, 75-80.

[20] T. Sowade, T. Liese, C. Schmidt, F. W. Schütze, X. Yu, H. Bernd, W. Grünert, J. Catal., 2004, 225, 105-115.

\section{Graphical Abstract}

Chin. J. Catal., 2018, 39: 1004-1011 doi: 10.1016/S1872-2067(18)63054-2

Bimetallic Cr-In/H-SSZ-13 for selective catalytic reduction of nitric oxide by methane

Jun Yang, Yupeng Chang, Weili Dai, Guangjun Wu, Naijia Guan, Landong Li * Nankai University

The bimetallic Cr-In/H-SSZ-13 catalyst exhibited appreciable reactivity and hydrothermal stability in the $\mathrm{CH}_{4}$-SCR process.

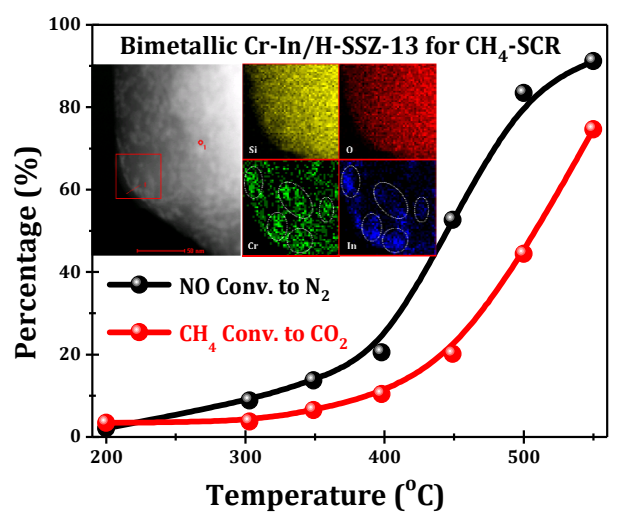


[21] R. Serra, M. J. Vecchietti, E. Miro, A. Boix, Catal. Today, 2008, 133-135, 480-486.

[22] H. Pan, Y. F. Jian, Y. K. Yu, N. N. Chen, C. He, C. He, Appl. Surf. Sci,, 2016, 390, 608-616.

[23] T. Maunula, J. Ahola, H. Hamada, Appl. Catal. B, 2006, 64, 13-24.

[24] J. M. Zamaro, M. A. Ulla, E. E. Miro, Catal. Today, 2005, 107-108, 86-93.

[25] O. A. Anunziata, A. R. Beltramone, F. G. Requejo, J. Mol. Catal. A, 2007, 267, 194-201.

[26] E. E. Miro, L. Gutierrez, J. M. R. Lopez, F. G. Requejo, J. Catal., 1999, $188,375-384$.

[27] M. Ogura, T. Ohsaki, E. Kikuchi, Microporous Mesoporous Mater., 1998, 21, 533-540.

[28] X. J. Zhou, Z. S. Xu, T. Zhang, L. W. Lin, J. Mol. Catal. A, 1997, 122, 125-129.

[29] E. Kikuchi, M. Ogura, I. Terasaki, Y. Goto, J. Catal., 1996, 161, 465-470.

[30] M. C. Campa, D. Pietrogiacomi, M. Occhiuzzi, Appl. Catal. B, 2015, 168-169, 293-302.

[31] S. W. Chen, X. L. Yan, J. Q. Chen, J. H. Ma, R. F. Li, Chin. J. Catal.,
2010, 31, 1107-1114.

[32] T. Tabata, M. Kokitsu, O. Okada, Appl. Catal. B, 1995, 6, 225-236.

[33] Y. J. Li, T. L. Slager, J. N. Armor, J. Catal., 1994, 150, 388-399.

[34] V. L. Sushkevich, D. Palagin, M. Ranocchiari, J. A. van Bokhoven, Science, 2017, 356, 523-527.

[35] F. Ayari, M. Mhamdi, J. Alvarez-Rodriguez, A. R. G. Ruiz, G. Delahay, A. Ghorbel, Appl. Catal. B, 2013, 134-135, 367-380.

[36] F. Ayari, M. Mhamdi, T. Hammedia, J. Alvarez-Rodriguez, A.R.G. Ruiz, G. Delahay, A. Ghorbel, Appl. Catal. A, 2012, 439-440, 88-100.

[37] J. M. Zamaro, E. E. Miro, A. V. Boix, A. Martínez-Hernandez, G. A. Fuentes, Microporous Mesoporous Mater., 2010, 129, 74-81.

[38] A. Hakuli, M. E. Harlin, L. B. Backman, A. O. I. Krause, J. Catal., 1999, $184,349-356$.

[39] M. Takahashi, T. Nakatani, S. Iwamoto, T. Watanabe, M. Inoue, Appl. Catal. B, 2007, 70, 73-79.

[40] S. B. Xie, M. P. Rosynek, J. H. Lunsford, J. Catal., 1999, 188, 32-39.

[41] T. Nakatani, T. Watanabe, M. Takahashi, Y. Miyahara, H. Deguchi, S. Iwamoto, H. Kanai, M. Inoue, J. Phys. Chem. A, 2009, 113, 7021-7029.

\title{
双金属 Cr-In/H-SSZ-13 催化剂上 $\mathrm{CH}_{4}$ 选择催化还原 NO
}

\author{
杨 俊 ${ }^{\mathrm{a}}$, 常煜鹏 ${ }^{\mathrm{a}}$, 戴卫理 ${ }^{\mathrm{a}}$, 武光军 ${ }^{\mathrm{a}}$, 关乃佳 ${ }^{\mathrm{a}, \mathrm{b}}$, 李兰冬 ${ }^{\mathrm{a}, \mathrm{b},{ }^{*}}$ \\ a南开大学材料科学与工程学院, 国家新材料研究院, 天津 300350 \\ $\mathrm{b}$ 南开大学先进能源材料化学教育部重点实验室, 化学化工协同创新中心, 天津 300071
}

\begin{abstract}
摘要: 天然气 (主要成分为甲烷) 储量丰富, 价格低, 随着国内电厂煤改气的进行, 甲烷作为还原剂选择催化还原氮氧化物 成为电厂烟气脱硝的理想选择, 受到广泛关注. In 改性分子篮催化剂在甲烷选择催化还原一氧化氮反应 $\left(\mathrm{CH}_{4}-\mathrm{SCR}\right)$ 中表现 出一定催化性能, 而 In 基双金属被认为是最有前景的 $\mathrm{CH}_{4}$-SCR 催化剂. 本文通过湿浸渍法制备了分子篎双金属催化剂, 并成功应用于 $\mathrm{CH}_{4}$-SCR. 我们首先研究了不同分子篎载体、助剂及含量、氧气浓度、甲烷浓度和空速对反应的影响, 发现 $0.5 \% \mathrm{Cr}-2 \% \mathrm{In} / \mathrm{H}-\mathrm{SSZ}-13$ 在 $\mathrm{CH}_{4}$-SCR中表现出最佳的催化性能: $\mathrm{NO}$ 转化率 $>90 \%, \mathrm{~N}_{2}$ 选择性 > $99 \%$ (反应条件: $550{ }^{\circ} \mathrm{C}, 6 \%$ $\mathrm{H}_{2} \mathrm{O}$, 空速 $\left.75000 / \mathrm{h}\right)$. 从透射电镜照片可以看出, $0.5 \% \mathrm{Cr}-2 \% \mathrm{In} / \mathrm{H}-\mathrm{SSZ}-13$ 催化剂上均匀分布纳米尺寸颗粒, 扫描透射-高角 环形暗场像元素分布分析表明 $\mathrm{Cr}$ 与 In 出现在同一个位置, 即 $\mathrm{Cr}$ 与 In 紧密接触. X射线光电子能谱结果表明, 与单金属催 化剂相比, 双金属催化剂中 In 的能谱发生了明显偏移, $\mathrm{Cr}$ 与 In 存在电子相互作用. $\mathrm{CH}_{4}$-SCR 反应活性实验发现, 双金属催 化剂活性远远超过单金属催化剂活性及其机械混合物, 表明 $\mathrm{Cr}$ 的添加可以明显促进 $\mathrm{In}$ 的活性. 换言之, 双金属催化剂中, $\mathrm{Cr}$ 与 In 存在协同催化作用. Cr-In/H-SSZ-13在严苛反应条件下的活性长期保持不变, 具有良好稳定性, 这与沸石分子笁载 体 H-SSZ-13 的高热稳定性分不开. 结合稳态反应与程序升温表面反应结果, 可以推测有氧条件下 $\mathrm{CH}_{4}$ 和 $\mathrm{NO}$ 分别在 $\mathrm{In}$ 和 $\mathrm{Cr}$ 位点上活化.
\end{abstract}

关键词: 选择催化还原; 一氧化氮; 甲烷; Cr-In/H-SSZ-13；双金属催化剂

收稿日期: 2018-02-07. 接受日期: 2018-03-07. 出版日期: 2018-05-05.

*通讯联系人. 电话/传真: (022)23500341; 电子信箱: lild@nankai.edu.cn

基金来源：国家自然科学基金 (21773127, 21722303, 21421001); 高等学校学科创新引智计划 (111计划, B18030).

本文的电子版全文由Elsevier出版社在ScienceDirect上出版(http://www.sciencedirect.com/science/journal/18722067). 